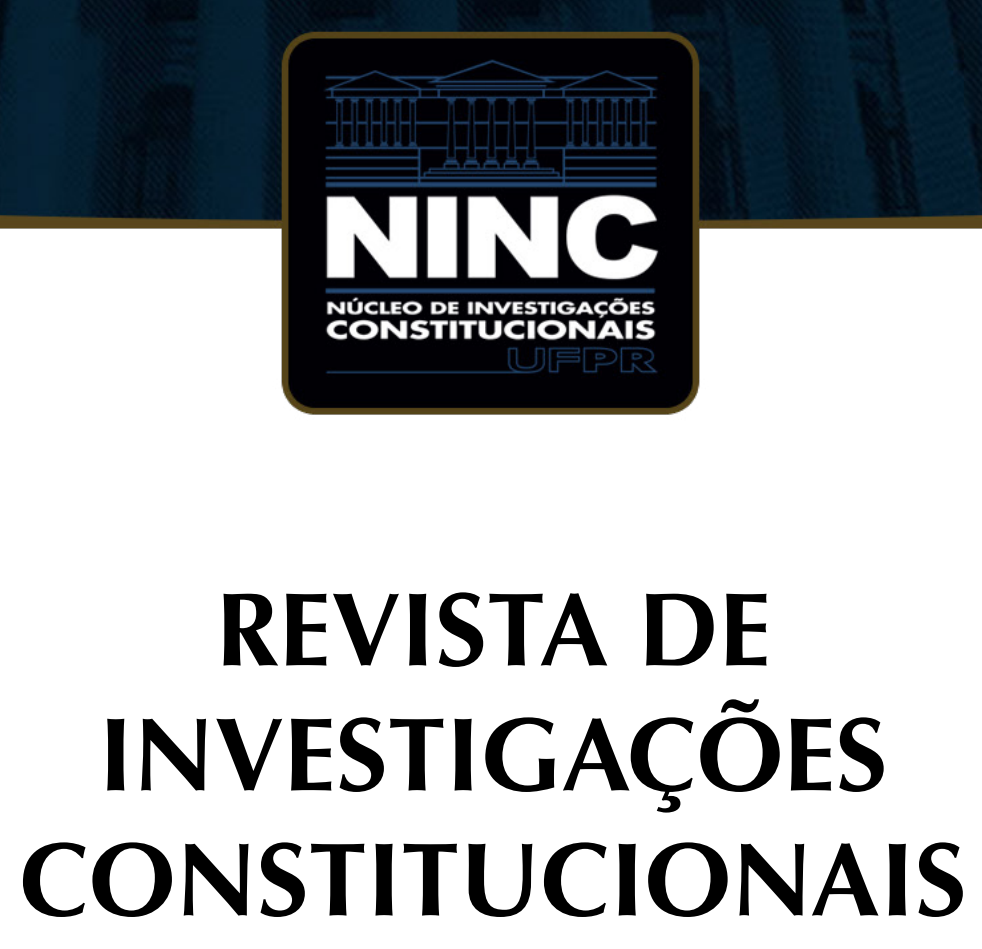

vol. 4 | n. 1 | janeiro/abril 2017 | ISSN 2359-5639 | Periodicidade quadrimestral Curitiba | Núcleo de Investigações Constitucionais da UFPR | www.ninc.com.br 


\title{
Reproductive Healthcare Services and the U.S. Supreme Court: Beyond Roe v. Wade and "Abortion Clinics"**
}

\section{Serviços de saúde reprodutiva e a Suprema Corte dos EUA: para além de Roe v. Wade e de "Clínicas de Aborto"}

\author{
KARLA A. VERGARA PÉREZ** \\ Boston College Law School (United States of America) \\ vergarak@bc.edu \\ Recebido/Received: 12.07 .2016 / July $12^{\text {th }}, 2016$ \\ Aprovado/Approved: 25.10.2016/ October 10th, 2016
}

Abstract

At a time when the United States is sharply divided on women's reproductive rights, the focus has shifted from legality to that of access to reproductive healthcare services. The binary (pro-choice/anti-choice) overlooks women who seek reproductive healthcare services for reasons other than abortion. Self-proclaimed sidewalk counselors approach these women to convince them that there are alternatives to abortion. In this way, the women who choose to ignore oftentimes risk being scolded, yelled at, harassed, and humiliated publicly. Many states have enacted buffer zone legislation to protect women trying to access reproductive healthcare clinics, but an overwhelming amount of these laws have been struck down by the U.S. Supreme Court, based on
Resumo

No momento em que os Estados Unidos estão fortemente divididos sobre os direitos reprodutivos das mulheres, o foco do debate passou da legalidade ao acesso a serviços de saúde. O binário (pró-escolha/anti-escolha) atinge muIheres que procuram os serviços de saúde reprodutiva para fins que não o aborto. Nesse contexto, alguns autoproclamados "conselheiros de calçada" abordam essas mulheres pelas ruas para convencê-las de que existem alternativas ao aborto. No entanto, as mulheres que optam por ignorá-los correm risco de ser repreendidas, perseguidas e humilhadas publicamente. Muitos estados aprovaram leis para proteger as mulheres que frequentam clínicas de saúde reprodutiva, mas uma enorme quantidade dessas leis foi declarada in constitucional pela Suprema Corte dos EUA, com base na

Como citar esse artigo/How to cite this article: VERGARA PÉREZ, Karla A., Reproductive Healthcare Services and the U.S. Supreme Court: Beyond Roe v. Wade and “Abortion Clinics". Revista de Investigações Constitucionais, Curitiba, vol.4, n. 1, p. 43-68,jan./abr. 2017. DOI: $10.5380 /$ rinc.v4i1.47660.

* My heartfelt thanks go to Professors M. Cathleen Kaveny and Natalya Shnitser for their thoughtful comments and guidance throughout the course of this project; to Caroline Reilly, who has inspired me to challenge the status quo and see women's reproductive rights for what they are: One of the most important civil rights issues of our generation; to Professor Richard Albert for his continued mentorship as I navigate the field of constitutional law; and to Peter Skeffington and David Ferrer because publication of this article would not have been possible without them.

** Juris Doctor - J.D. Candidate (2017) at Boston College Law School (Boston, United States of America). Bachelor of Arts - B.A. 2011, Cornell University. E-mail: vergarak@bc.edu. 
the First Amendment rules. This article argues that sidewalk counselors and activists' protesting against abortion outside of these clinics is futile, defending that buffer zones around reproductive healthcare facilities help protect women's privacy and their right to access so they may obtain the reproductive healthcare they are entitled to receive.

Keywords: reproductive healthcare clinics; abortion clinics; first amendment; sidewalk counselors; Roe v. Wade.
Primeira Emenda. Este artigo argumenta que o protesto dos "conselheiros de calçada" é fútil e defende que devem ser elaboradas leis que protejam a privacidade das mulheres $e$ seu direito de acesso ao serviço de saúde reprodutiva, a fim de que possam obter os cuidados médicos que têm direito.

Palavras-chave: clínicas de saúde reprodutiva; clínicas de aborto; Primeira Emenda; conselheiros de calçada; Roe v. Wade.

\section{CONTENTS}

1. Introduction; 1.1. A Violent History; 1.2. The Buffer Zone Tug O'Wars; 2. Analysis; 2.1. RHCCs: Much More than "Abortion Clinics"; 2.2. Who is Seeking an Abortion?; 2.3. Who is a "Sidewalk Counselor"?; 2.4. Buffer Zones in Other Contexts; 2.4.1. The (Military) Funeral Context; 2.4.2. The Polling Place Context; 2.4.3. The Buffer Zone Around the Supreme Court. 3. Conclusion; 4. References.

\section{INTRODUCTION}

In the forty-three years since the decision in Roe $v$. Wade, ${ }^{1}$ the abortion debate in the United States has continued to be one of the most fiercely discussed areas in contemporary American politics and society. ${ }^{2}$ Dr. Jane Hodgson, an abortion provider in the 1990s, expressed through her scholarship that she had never seen the intensity of the United States' divisions over reproductive choice despite having travelled to four different continents. 3 In 2013, television host Rachel Maddow commemorated Roe's 40th anniversary by highlighting the ongoing friction between demonstrators in favor of and against abortion rights and interviewing the clinical staff caught in the middle of the debate. ${ }^{4}$ During the segment, Ms. Nancy Keenan, then President of NARAL

\footnotetext{
1 In Roe v. Wade, 410 U.S. 113 (1973), the Court held that women have a constitutionally protected, fundamental right under the Fourteenth Amendment to a safe abortion. However, please note that Justice Ruth Bader Ginsburg has challenged this interpretation of the case, arguing that the decision was less about a woman's right to choose to have an abortion than it was about a doctor's autonomy to carry out abortions. HEAGNEY, Meredith. "Justice Ruth Bader Ginsburg Offers Critique of Roe v. Wade During Law School Visit", May 15, 2013. Available at: <http://www.law.uchicago.edu/news/justice-ruth-bader-ginsburg-offers-critique-roe-v-wade-during-law-school-visit>. "Roe isn't really about the woman's choice, is it? It's about the doctor's freedom to practice... it wasn't woman-centered, it was physician-centered."

2 See Stenberg v. Carhart, 530 U.S. 914, 947 (2000) (O'Connor, J., concurring).

3 HODGSON, Jane E. Violence Versus Reproductive Health Care: In The United States Organised Medicine Averts Its Gaze. British Medical Journal, London, vol. 310, n. 6979, mar. 1995. pp. 547-548. Available at: <http://dx. doi.org/10.1136/bmj.310.6979.547>.

4 “Rachel Maddow Celebrates Roe v. Wade On Its 40th Anniversary", Video, Huffington Post: HuffPost Media, Jan. 23, 2013. Available at: <http://www.huffingtonpost.com/2013/01/23/rachel-maddow-roe-v-wade-anniversary_n_2533025.html>.
} 
Pro-Choice America, 5 remarked that, contrary to popular belief, the debate around abortion is "no longer about the legality" of it, like it was before Roe was decided, but that "it has now become a debate and a fight around access." ${ }^{6}$ Anti-abortion and pro-choice activists have defined the nature of the abortion dispute in binary terms for years, excluding, I suggest, one important group from the conversation: Women who seek low-cost, routine healthcare from reproductive healthcare clinics ("RHCCs" or "RHCFs") that simply happen to offer abortion services.

Subpart 1.1 of this Introduction will briefly discuss the history of violence against RHCCs in the United States. Subpart 1.2 will then discuss buffer zone laws as reactive legal mechanisms to protect access to RHCCs and their mixed results in the court system when challenged. The Analysis section of the article (Section 2 and all its subparts) will challenge the U.S. Supreme Court's reasons for striking down buffer zone laws on a First Amendment basis by articulating the importance of such laws beyond the previously expressed concerns involving harassment. Finally, the Conclusion (Section 3) aims to provoke additional thought and inquiry into why, as a society, we are willing to uphold buffer zones in certain contexts, but our skepticism is heightened when it comes to women's reproductive healthcare, particularly when abortion is involved.

\subsection{A Violent History}

The Arkansas physician who participated in the Rachel Maddow interview the only abortion provider in the state at that point - asked for his identity to be concealed for security concerns. ${ }^{7}$ In extreme cases, anti-abortion activists have engaged in acts of violence against the RHCCs that offer abortion services and the physicians and staff that carry out the procedure. 8 To put matters into perspective, a number of

\footnotetext{
5 "NARAL" used to stand for "National Abortion and Reproductive Rights Action League," but its name was changed to "NARAL Pro-Choice America" in 2003. NARAL Pro-Choice America Foundation and NARAL Pro-Choice America, Inc. are 501(c)(3) and 501(c)(4) non-profit organizations, respectively, dedicated to reproductive advocacy across the United States. See LEE, Jennifer 8. "Abortion Rights Group Plans a New Focus and a New Name", N.Y. Times, Jan. 5, 2003. Available at: < http://www.nytimes.com/2003/01/05/us/abortion-rights-group-plans-a-new-focus-and-a-new-name.html?_r=0>. See also "About Us, NARAL Pro-Choice America". Available at: <http://www.prochoiceamerica.org/about-us/>; "Mission Statements, NARAL Pro-Choice America". Available at: <http://www.prochoiceamerica.org/about-us/mission-statements.html>.

6 Supra note 4 (emphasis supplied). See also FINER, Lawrence B.; FROHWIRTH, Lori F. et al. Reasons U.S. Women Have Abortions: Quantitative and Qualitative Perspectives. Perspectives on Sexual and Reproductive Health, [s.I.], vol. 37, n. 3, pp. 110-118, sep. 2005: "Public discussion about abortion in the United States has generally focused on policy: who should be allowed to have abortions, and under what circumstances."

7 See supra note 4 .

8 See idem. See also FREEDMAN, Lori. Willing and Unable: Doctor's Constraints in Abortion Care, at p. 17 (Vanderbilt Univ. Press 2010); HORVATH-COSPER, Diane J. “Being a doctor who performs abortions means you always fear your life is in danger", Wash. Post, Oct. 29, 2015. Available at: <https://www.washingtonpost. com/posteverything/wp/2015/10/29/being-a-doctor-who-performs-abortions-means-you-always-fear-your-life-is-in-danger/>; ROHTER, Larry. “Doctor is Slain During Protest Over Abortions”, N.Y. Times, Mar. 11, 1993.
} 
anti-abortion activists have committed numerous acts of violence since the 1970s, including eleven murders, 917 attempted murders, 185 arsons, 10 and 1,495 acts of vandalism. ${ }^{11}$ For instance, in 1993, anti-abortion protester Michael F. Griffin was arrested and charged for murder in Florida after shooting Dr. David Gunn, a 47-year-old abortion-providing physician who had just opened the Pensacola Women's Medical Services clinic earlier that year. ${ }^{12}$ In 1994, John C. Salvi III walked into two RHCCs in Brookline, Massachusetts, killed two receptionists, and injured five clinic workers. ${ }^{13}$ Also in 1994, Paul Hill — a minister - shot and murdered Dr. John Britton, an abortion provider, and his bodyguard outside the Ladies Center clinic in Pensacola, Florida. ${ }^{14}$ Hill was executed in 2003 for these murders. ${ }^{15}$ In 2009, Dr. George Tiller, whose Kansas clinic had been subjected to years of protest and harassment - including a bombing incident - was murdered in his own church. ${ }^{16}$ Recently, on November 27, 2015, as many as twelve people 17 were victims of a shooting directed at a Planned Parenthood facility in Colorado Springs, Colorado.18 The accused gunman, Robert Lewis Dear, self-identified

9 This figure has been updated to include the murders that occurred during the Colorado Springs Planned Parenthood shooting in November of 2015. SHOICHET, Catherine E.; STAPLETON, AnneClaire; BOTELHO, Greg. “Colorado Planned Parenthood shooting: 3 killed", CNN, Nov. 27, 2015. Available at: <http://www.cnn. com/2015/11/27/us/colorado-shooting-probe/>.

10 This number has been updated to reflect the four arsons that occurred in the summer of 2015 after accusatory Planned Parenthood videos were released. MORLIN, Bill. "Four Arsons in 74 Days at Planned Parenthood Clinics", Southern Poverty Law Center, Oct. 2, 2015. Available at: <https://www.splcenter.org/hatewatch/2015/10/02/four-arsons-74-days-planned-parenthood-clinics.>.

11 FILIPOVIC, Jill. “Abortion Clinic Protesters: "Sidewalk Counselors" or “Sidewalk Terrorists"?", Cosmopolitan, Nov. 17, 2014. Available at: <http://www.cosmopolitan.com/politics/a32624/boston-abortion-planned-parenthood-protests/>. See also supra note 9.

12 See ROHTER, supra note 8.

13 See supra note 11; CLARKSON, Frederick. "Remembering John Salvi and the Brookline Clinic Shootings", Political Research Associates, Jan. 15, 2014. Available at: <http://www.politicalresearch.org/2014/01/15/ remembering-john-salvi-and-the-brookline-clinic-shootings/\#sthash.Q3abL41W.dpbs.>.

14 CLAIBORNE, William. "Two Killed at Clinic in Florida”, Wash. Post: Nation Special Report, Jul. 30, 1994. Available at: <http://www.washingtonpost.com/wp-srv/national/longterm/abortviolence/stories/florida.htm>.

15 GOODNOUGH, Abby. “Florida Executes Killer of an Abortion Provider”, N.Y. Times, Sep. 4, 2003. Available at: <http://www.nytimes.com/2003/09/04/us/florida-executes-killer-of-an-abortion-provider.html>.

16 See supra note 8.

17 See supra note 10; TSENG, Hsing; AEGERTER, Macradee. "Planned Parenthood shooting victims remembered by family, friends", KDVR, Nov. 29, 2015. Available at: <http://kdvr.com/2015/11/29/planned-parenthood-shooting-victims-remembered-by-family-friends/>; "Death of UCCS police officer in Colorado Springs Planned Parenthood shooting confirmed", The Gazette, Dec. 1, 2015. Available at: <http://gazette.com/death-of-uccs-police-officer-in-colorado-springs-planned-parenthood-shooting-confirmed/article/1564442>.

18 See supra note 9. 
as an anti-abortionist and confessed 19 that he was acting as "a warrior for the babies."20 The President and CEO of Planned Parenthood of the Rocky Mountains, Vicki Cowart, called for an end to these kinds of violent attacks, stating that "[i]t is time to put an end to the dangerous rhetoric that has permeated our political conversations ... [T] his violence, whether inflicted with words or with weapons, cannot become our normal."21 The former president of the American Bar Association and nationally prominent First Amendment advocate Talbot D'Alemberte noted in connection to the hostility surrounding RHCCs: "This is not debate. It's intimidation. If [the anti-abortion activists'] purpose is to communicate a message, they can be heard" without having to resort to harassment.22 At a minimum, women who seek reproductive services from an RHCC, as well as the clinical staff, are subjected to harassment. Horvath-Cosper has stated that being an obstetrician-gynecologist has "made [her] a target for harassment online and in person over the course of [her] career. Unfortunately, [her] experience is not the exception among [her] colleagues" despite performing a legally medical procedure in all fifty states. ${ }^{23}$ These acts of violence, though rare, instill fear in women and ultimately deter them from seeking professional reproductive healthcare from these clinics, even if the service they seek is not abortion. ${ }^{24}$ For the women who do seek an abortion, recent studies and reports have shown that women who do not readily have access to one attempt to either self-induce 25 or to have the procedure done under more dangerous conditions that raise additional health risks. 26

\footnotetext{
19 It should be noted that the court has recently declared that the accused is unfit to stand trial. HEALY, Jack. "Judge Finds Planned Parenthood Suspect Unfit for Trial", N.Y. Times, May 11, 2016. Available at: <http:// www.nytimes.com/2016/05/12/us/judge-declares-planned-parenthood-suspect-unfit-for-trial.html?smpro$\mathrm{d}=$ nytcore-iphone\&smid=nytcore-iphone-share\&_r $\mathrm{r}=0 .>$.
}

20 HUGHES, Trevor. “Accused Planned Parenthood Gunman Says He's Guilty”, USA Today, Dec. 9, 2015. Available at: <http://www.usatoday.com/story/news/2015/12/09/accused-planned-parenthood-gunman-could-face-death-penalty-charges--3-deaths/77038542/.>.

21 Idem.

22 SAVAGE, David G. “Justices to Enter Abortion Clinic's 'Buffer Zone': Supreme Court: A case of 'free speech versus free access' at a surgical center is high court's first chance to weigh aggressive protesters' First Amendment rights", L.A. Times, Apr. 24, 1994. Available at: <http://articles.latimes.com/1994-04-24/news/mn49919_1_supreme-court/2>.

23 HORVATH-COSPER, supra note 8.

24 See supra note 8.

25 See, e.g., BEUSMAN, Callie. "100,000 Women in Texas Have Tried to Self-Induce an Abortion, New Report Says", Broadly, Nov. 17, 2015. Available at: <https://broadly.vice.com/en_us/article/100000-women-in-texas-have-tried-to-self-induce-an-abortion>.

26 During the oral arguments for Roe v. Wade on December 13, 1971, Attorney Sarah R. Weddington, arguing on behalf of the Plaintiffs, brought to light the consequences of obstructing access to safe abortions: "In the absence of abortions, or legal medically safe abortions, women often resort [sic] to the illegal abortions, which certainly carry risks of death, all the side effects, such as severe infections, permanent sterility, all the complications that result. And, in fact, if the woman is unable to get [. . . ] legal abortion [. . . ] she can do a self-abortion, which is [. . .] by far the most dangerous." Oral Argument at 12:45, Roe v. Wade, 410 U.S. 113 (1973) (No. 7018), https://www.oyez.org/cases/1971/70-18. See KHAZAN, Olga. “Texas Women Are Inducing Their Own 
Physicians who provide abortion services also often end up fearing for their family members' lives as well as their own.27 The recent Colorado shooting casted light upon an issue advocates for women's reproductive healthcare know all too well: Approaching these so-called abortion clinics is anything but safe. 28 On March 30th, 2016, the Peoria County Airport in Illinois had to be shut down after the authorities discovered "suspicious items" in a woman's carry-on luggage. ${ }^{29}$ After further investigation, the authorities discovered that the woman was an employee of the National Abortion Federation (NAF), whose job required her to travel around the country training RHCC staff members on how to identify bombs so they could protect themselves and patients from attacks; she uses the dynamite-resembling dog toys found in her carry-on luggage as training devices. 30

Despite the fact that Roe and its progeny are still good law, 31 women in the U.S. have a hard time accessing reproductive healthcare at RHCFs without feeling like their privacy and safety are threatened by the anti-abortion activists who surround these clinics. These attacks have driven abortion providers to demand legislation that guarantees safe, unobstructed access to RHCCs, 32 such as buffer zone laws, which have had an underwhelming rate of success across the country due to First Amendment concerns.

In 1994, then President Clinton signed the Free Access to Clinic Entrances Act ("FACE Act") in an effort to put an end to acts of violence against RHCFs. 33 The FACE Act prohibited anyone from threatening or forcibly interfering with people entering an RHCF or intentionally damaging the clinic. ${ }^{34}$ Since then, many states have passed protective buffer zone laws that prohibit anti-abortion activists from harassing women

\footnotetext{
Abortions", The Atlantic, Nov. 17, 2015. Available at: <http://www.theatlantic.com/health/archive/2015/11/ texas-self-abort/416229/.>.

27 See HORVATH-COSPER, supra note 8.

28 See idem.; ROHTER, supra note 8.

29 MADDOW, Rachel. "Donald Trump Exposes Truth of Anti-Abortion Politics”, Video, MSNBC News: The Rachel Maddow Show, Apr. 1, 2016. Available at: <https://www.youtube.com/watch?v=wkV7H1NEJk4>.LAMANSKY, Katrina. "Dog toys, and safety training items for abortion clinics, are what shut down Peoria airport", WQAD, Mar. 31, 2016. Available at: <http://wqad.com/2016/03/31/photo-shows-what-tsa-agents-saw-inside-peoria-airport-passengers-bag-that-prompted-evacuation/>.

30 See supra note 29.

31 The holding in Planned Parenthood of Southeastern Pennsylvania v. Casey, 505 U.S. 833 (1992), later solidified the central holding of Roe v. Wade, namely, that a woman has a constitutionally protected right to seek an abortion until fetal viability.

32 ALBERT, Richard. Protest, Proportionality, and the Politics of Privacy: Mediating the Tension Between the Right of Access to Abortion Clinics and Free Religious Expression in Canada and the United States. Loyola of Los Angeles International and Comparative Law Review, Los Angeles, vol. 27, n. 1, p. 1-62, jan./apr. 2005. p. 9.

33 See FILIPOVIC, supra note 11.

34 Codified at 18 U.S.C. $§ 248$.
} 
who approach RHCCs. 35 Buffer zones, 36 as discussed in this article, are areas surrounding RHCC property lines in order to keep both anti-abortion activists and peaceful counselors away from the clinics' premises, and therefore minimize the possibility of harassment and violence towards the women entering the clinics. ${ }^{37}$ Courts have recognized that there are two types of buffer zones: Fixed and floating. Fixed buffer zones surround a particular, immovable area (such as a parking lot, a driveway, an entrance, a facility, etc.); floating buffer zones, on the other hand, apply to persons, vehicles, or mobile entities entering or exiting the protected facilities. 38 Buffer zones are employed successfully in settings unrelated to RHCFs. The question is why.

\subsection{The Buffer Zone Tug $O^{\prime}$ Wars}

The jurisprudence around buffer zone laws has not always held that a person's right to free speech outweighs another's right to privacy. ${ }^{39}$ Frisby v. Schultz was one of the first cases to deal with this difficult tension. In that case, two abortion opponents challenged a city ordinance 40 which banned picketing "before or about" any particular residence because they wanted to protest abortion on a public street outside an abortion-providing physician's home. 41 They had engaged in this activity"on at least six occasions" between April and May of 1985 with a group of eleven to forty people.42 Although the picketing was "generally orderly and peaceful," it had generated "substantial

\footnotetext{
35 See, e.g., Colo. Rev. Stat. § 18-9-122(3) (1999); M.G.L.A. 266 § 120E1/2 (2001). See FILIPOVIC, supra note 11. 36 Buffer Zone, Merriam-Webster's Learner's Dictionary, http://www.merriam-webster.com/dictionary/buffer\%20zone (last visited Apr. 18, 2016). The term "buffer zone" as "an area that keeps two things separated;" "a neutral area separating conflicting forces;" and "an area designed to separate."

37 EDWARDS, Jamie. McGuire v. Reilly: The First Amendment and Abortion Clinic Buffer Zones in the Wake of Hill v. Colorado. UC Davis Law Review, Davis, vol. 36, n. 3, p. 787-812, feb. 2003. p. 789. See also BASSETT, Laura. "Abortion Clinic Buffer Zones Crumble Around the Country", Huffington Post, Jul. 9, 2014. Available at: <http://www.huffingtonpost.com/2014/07/09/abortion-clinic-buffer-zo_n_5571516.html>.

38 Rodney A. Smolla, 1 Smolla \& Nimmer on Freedom of Speech § 13:38, Chapter 13: Free Speech and Civil Rights Enforcement, at p. 2.

39 See, e.g., the following seminal decisions, which discuss access to abortion: McCullen v. Coakley, 134 S. Ct. 2518 (2014), Hill v. Colorado, 530 U.S. 703 (2000), Schenck v. Pro-Choice Network of Western New York, 519 U.S. 357 (1997), Madsen v. Women's Health Center, Inc., 512 U.S. 753 (1994), Planned Parenthood of Southeastern Pennsylvania v. Casey, 505 U.S. 833 (1992), Frisby v. Schultz, 487 U.S. 474 (1988), and Roe v. Wade, 410 U.S. 113 (1973). For practical purposes, I will only discuss at length the cases that are most relevant to my analysis for this paper.

40 The relevant text of the ordinance read as follows: "It is unlawful for any person to engage in picketing before or about the residence or dwelling of any individual in the Town of Brookfield." The ordinance also states the primary purpose of this ban: "the protection and preservation of the home" through assurance "that members of the community enjoy in their homes and dwellings a feeling of well-being, tranquility, and privacy." Frisby, 487 U.S. at p. 477.

41 Idem. at p. 476.

42 Idem.
} 
controversy and numerous complaints." 43 The Court reasoned that the ordinance left "ample alternative channels of communication" (i.e., it allowed protestors to enter and march through neighborhoods, alone or in groups, distribute literature from door to door, and contact the residents by telephone). ${ }^{44}$ Because there were ample alternative channels of communication, the Court concluded that the city ordinance was narrowly tailored. 45 The Court, however, also recognized that "protection of the unwilling listener" is one of the State's paramount concerns when it comes to residential privacy. 46 Since the ordinance was narrowly tailored to ban protesting targeted at a particular residence in order to protect the privacy of the home, which is considered a "substantial and justifiable" state interest, the Court concluded that the ordinance was valid. 47

In the case of Hill v. Colorado, 48 the U.S. Supreme Court upheld in a 6-3 opinion a Colorado buffer zone statute that makes it unlawful for any person within 100 feet of any healthcare facility entrance to "knowingly approach" within eight feet of another person without their consent "for the purpose of passing a leaflet or handbill to, displaying a sign to, or engaging in oral protest, education, or counseling with such other person..." if the person is unwilling to accept and listen to the message. 49 The Supreme Court upheld the statute, finding that " $[t]$ he State of Colorado ha[d] responded to its substantial and legitimate interest in protecting these persons from unwanted encounters, confrontations, and even assaults by enacting an exceedingly modest restriction on the speakers' ability to approach."50 Underlying the Hill decision, however, was an incredibly important leap forward: The Court's explicit acknowledgment of the "significant difference between state restrictions on a speaker's right to address a willing audience and those that protect listeners from unwanted communication" when addressing the government's significant interest prong of the strict scrutiny analysis. 51 Furthermore, the Court explicitly recognized that "[p]ersons who are attempting to enter health care facilities - for any purpose - are often in particularly vulnerable physical and emotional conditions." 52 Hospitals, it reasoned, are facilities "where human ailments

\footnotetext{
43 Idem.

44 Idem. at p. 484.

45 See idem. at pp. 482, 487-88. mar. 2000/2001. p. 385.

48 Hill v. Colorado, 530 U.S. 703 (2000).

49 Idem. at pp. 707-08.

50 Idem. at p. 729.

51 Idem. at pp. 715-16 (emphasis supplied).

52 Idem. at p. 729 (emphasis supplied).
}

46 Idem. at p. 484 (citing to Carey v. Brown, 447 U.S. 455, 471 (1980): "The State's interest in protecting the well-being, tranquility, and privacy of the home is certainly of the highest order in a free and civilized society."

47 See idem. at p. 488. See also COWAN, Kristen G. The Tailoring of Statutory Bubble Zones: Balancing Free Speech and Patients' Rights. Journal of Criminal Law \& Criminology, Boston, vol. 91, n. 2, pp. 385-428, dic./ 
are treated, where patients and relatives alike often are under emotional strain and worry, where pleasing and comforting patients are principal facets of the day's activity, and where the patient and [her] family... need a restful, uncluttered, relaxing, and helpful atmosphere."53

As a result of the recurring violence RHCCs were being subjected to around the state, the Massachusetts legislature first enacted the Massachusetts Reproductive Health Care Facilities Act (hereafter "the Act") in 2000, which is coded at Chapter 266, Section 120E $1 / 2$, of the Massachusetts General Laws. 54 Modeled after Colorado's buffer zone law, 55 the Act's subsection (b) prescribed two buffer zones: One fixed and one floating. The statute made it illegal for persons "in the public way or sidewalk area" within an 18-foot radius of an RHCF entrance to "knowingly approach another person ... within six feet ... unless such other person ... consents" for the purpose of passing a leaflet, displaying a sign, engage in oral protest, education, or counseling. 56 The buffer zone statute allowed for anybody to step into the 18-foot fixed buffer zone area, but once within it, every individual was subject to six-foot floating buffer zone, which could not be penetrated unless the other person consented. 57

By 2007, it had become evident to law officials that the floating buffer zone portion of the statute was being routinely violated by protesters who continued to approach patients and clinical staff without due consent; they consequently rendered the statute ineffective and unenforceable. 58 The Massachusetts legislature introduced the revised statute that same year, which replaced the floating/fixed buffer zone rule with a fixed 35-foot buffer zone. ${ }^{59}$ The revised provision made it illegal to "knowingly enter or remain on a public way or sidewalk adjacent to a reproductive health care facility within a [fixed] radius of 35 feet of any portion of an entrance, exit or driveway . .."60 of "any place, other than a hospital, where abortions are performed"61 during the facility's business hours and only if the radius is "clearly marked and posted." 62 The revised statute faced anti-abortionist backlash almost immediately. In January 2008 , about two months after the revised statute had gone into effect, the Plaintiffs filed the initial action challenging the constitutionality of the Act.63

\footnotetext{
53 Idem. at pp. 728-29 (quoting NLRB v. Baptist Hospital, Inc., 442 U.S. 773, 783-84 (1979)) (emphases supplied). 
The First Circuit Court held that the Act was not unconstitutionally vague or an unlawful constriction of free speech based on three main arguments. ${ }^{64}$ First, that the Act was content-neutral because it was "enacted in response to legitimate safety and law enforcement concerns" and "without reference to the content of any speech," thus serving "a legitimate governmental interest unrelated to expressive content." 65 Second, the Court held that the Act successfully remedied "the ineffectiveness of the preexisting law" by being "narrowly tailored to serve important governmental interests in enhancing public safety around RHCF entrances" and "without burdening substantially more speech than necessary." 66 And third, the Court held that the Act leaves "open ample alternative channels of communication, because it 'places no burden at all on the plaintiffs' activities outside the 35-foot buffer zone."'67After the lower courts upheld the constitutionality of the Act based on the time, place, and manner doctrine, the Plaintiffs filed a petition for writ of certiorari with the U.S. Supreme Court on March 25, 2013.68

Time, place, and manner restrictions provide that the right to free speech granted by the First Amendment is not absolute.69 A State's time, place, and manner regulations are constitutional if they (1) do not regulate speech based on its content or subject matter, (2) are narrowly tailored to serve a significant governmental interest, and (3) leave open ample alternative channels for communication of the information. 70 The simple yet loaded question before the Supreme Court was whether the statute violated Petitioners' free speech rights under the First Amendment.71 During oral arguments, the State of Massachusetts articulated an array of reasons as to why the statute should be allowed to stand under the time, place, and manner doctrine. ${ }^{72}$ Even though the State never explicitly mentioned harassment, they alluded to the violent history clinics have been subjected to. ${ }^{73}$ To rebut, Petitioners argued that they were simply sidewalk counselors seeking to engage the women and discuss alternatives outside an abortion with them. ${ }^{74}$ The two competing characterizations of the nature of Petitioners' intentions and actions captured the attention of Justice Roberts and Justice Scalia,

64 See Brief for the Defendants-Appellees, McCullen v. Coakley, 708 F.3d 1 (2013) (No. 12-1334), 2012 WL 2872265 , at $* 2$.

65 Idem. at *3.

66 Idem.

67 Idem. (citing to McCullen v. Coakley, 571 F.3d 167, 176-78 (1st Cir. 2009)).

68 See Brief for Petitioner, McCullen v. Coakley, 134 S. Ct. 2518 (2014) (No. 12-1168), 2013 WL 1247969.

69 See COWAN, supra note 47, at pp. 385-86.

70 Clark v. Community for Creative Non-Violence, 468 U.S. 288, 293 (1984); Regan v. Time, Inc., 468 U.S. 641,648 (1984); Ward v. Rock Against Racism, 491 U.S. 781, 782-83 (1989).

71134 S. Ct. at p. 2525.

72 Oral Argument at 4:08, McCullen v. Coakley, 134S. Ct. 2518 (2014), https://www.oyez.org/cases/2013/12-1168.

73 Idem. at 43:29.

74 See idem. at 37:55. 
eventually persuading the bench to arrive at the same conclusion: "Petitioners are not protesters."75

When the unanimous McCullen v. Coakley decision was announced, supporters of the buffer zone statute quickly pointed out the "irony" and "hypocrisy" embedded in the Court's ruling. ${ }^{76}$ For instance, Marty Walz, then CEO of the Planned Parenthood League of Massachusetts, stated: "By striking down the buffer zone law today, the Supreme Court has taken away an essential measure to protect public safety and health care access in our state." 77 Another piece stated, "It's virtually impossible to square the law enforcement definition of illegal protest with the snuggly warm vision of political protest put forth by a unanimous Supreme Court only two months ago in McCullen v. Coakley."78 The statement made by the McCullen decision, however, went beyond simply making it more difficult for women to access reproductive healthcare. I submit that the Court's decision implicitly affirmed that, as a society, we are willing to place a higher value on free speech than on women's right to privacy when it comes to their reproductive healthcare. The question, once again, is why.

\section{ANALYSIS}

\subsection{RHCCs: Much More than "Abortion Clinics"}

After Roe made access to a safe abortion a constitutional right, the medical profession had to determine how abortion care would be provided.79 Lori Freedman - a scholar who explores the intersection between abortion politics and the medical profession - argues that, "given the larger threats to medical autonomy after abortion became legal, abortion services seem to garner support from mainstream medical associations only at moments when medical autonomy was threatened." 80 Abortion was

\footnotetext{
75134 S. Ct. at 2536 (emphasis supplied). See also Brief for Plaintiff-Appellants, supra note 63, at *3-4:"Plaintiffs are seven individual Massachusetts residents who engage in peaceful speech outside abortion clinics in the State. . Accordingly, Plaintiffs seek to offer women love, support, and information about alternatives to abortion, as well as assistance in carrying their babies to term."

76 See, e.g., MILLIGAN, Susan. “High Court Hypocrisy', U.S. News: Opinion, Jun. 27, 2014. Available at: <http:// www.usnews.com/opinion/blogs/susan-milligan/2014/06/27/supreme-court-bans-abortion-clinic-buffer-zones-but-keeps-its-own>. LOGIURATO, Brett. "Here's the Ultimate Irony of the Supreme Court Banning 'Buffer Zones' at Abortion Clinics", Business Insider, Jun. 27, 2014. Available at: <http://www.businessinsider.com/supreme-court-abortion-buffer-zones-decision-2014-6>. KILLIAN, Linda. "Supreme Hypocrisy on Buffer Zones?", Wall St. J.: Washington Wire, Jun. 27, 2014. Available at: <http://blogs.wsj.com/washwire/2014/06/27/supreme-hypocrisy-on-buffer-zones/>.

77 Logiurato, supra note 76.

78 LITHWICK, Dahlia; WEST, Sonja. "Advice for Ferguson from the Supreme Court". Available at: <http:// digitalcommons.law.uga.edu/fac_pm/190>.

79 Freedman, supra note 8 at p. 22.

80 Idem. at p. 21.
} 
never integrated with mainstream medical practice or education and, even today, only a minority of doctors 81 and hospitals offer the service. 82

Freedman further argues that the "net effect of the medical profession's non-committal orientation toward abortion care" has thwarted "efforts by abortion rights advocates within medicine to legitimize abortion as a normal reproductive health need."83 Although Freedman's isolation-makes-targeted-violence-easier argument is strong, I submit that it is unclear that this isolation is the result of physicians' non-committal attitudes towards reproductive rights per se. For instance, Sonia M. Suter criticizes the Supreme Court's upholding of a partial-birth abortion ban in Gonzales v. Carhart because the slim evidence on which the Court relied upon to uphold that ban was "contradicted by a notable group of medical experts." 84 She further remarks that this was in "direct contrast to an expansive vision of procreative liberty." 85 Finally, Freedman adopts Dr. Hodgson's argument, which advances that by being deprived of the "protection of anonymity within hospital walls" and forced into isolation as freestanding clinics, RHCCs are "more vulnerable to violence and harassment." 86

Today, women across the U.S. choose to go to RHCCs for a wide range of reasons. First, Planned Parenthood affiliates participate in Title $X,{ }^{87}$ the only federal funding program that allows family-planning clinics to supplement or reimburse Medicaid patients for reproductive healthcare services rendered, such as birth control, gynecological care, and other reproductive healthcare services that would otherwise be inaccessible to

81 See idem. ("Since abortion was legalized in 1973, the lack of mainstream institutional and organizational support for it has ultimately resulted in the marginalization of abortion care into freestanding abortion clinics served by politically motivated physicians.") (emphasis supplied). A close friend and medical student of obstetrics and gynecology at the University of Puerto Rico School of Medicine - whose curricula is the same as that offered in medical schools on the mainland - confirmed that instruction on abortion procedure varies from school to school and that medical students who do not wish to participate in the procedure may opt out of it, even if they are doing a family-planning rotation. She made it clear that this opt-out practice is unique to the abortion situation.

82 See idem. at p. 22 ("Regardless of medicine's interest in maintaining abortion turf, recent decades witnessed a steady decrease in the number of physicians providing abortion in their private practices and hospitals...").

83 Idem. at p. 21.

84 SUTER, Sonia M. The "Repugnance" Lens of Gonzales v. Carhart and Other Theories of Reproductive Rights: Evaluating Advanced Reproductive Technologies. The George Washington Law Review, Washington, vol. 76, n. 6, pp. 1514-1598, nov./dic. 2008. p. 1587.

85 Idem.

86 See Freedman, supra note 8 at p. 20 (citing to HODGSON, supra note 3 at p. 548).

87 Title $X$ is part of the United States Public Health Service Act, coded at 42 U.S.C. Ch. 6 A, $\S \S 300-300 a-8$, which is devoted solely to family planning services. Note that the federal funds are prohibited from being used for abortion unless the woman has been a victim of sexual assault or incest. See LOBIANCO, Tom. "Planned Parenthood president grilled at House hearing", CNN, Sep. 30, 2015. Available at: <http://www.cnn. com/2015/09/29/politics/planned-parenthood-hearing-cecile-richards/>; MADDOW, Rachel. “Planned Parenthood president stands up to House GOP grilling", at 5:32, Sep. 30, 2015. Available at: <https://www. youtube.com/watch?v=bB-y2DKU6Vs>. 
women who cannot pay full price. 88 According to the Guttmacher Institute, 89 Planned Parenthood clinics were $13 \%$ of the Title $X$ clinics and served $37 \%$ of Title X clients. 90 Low-income women who cannot, for whatever reason, 91 access hospitals or RHCCs, such as Planned Parenthood, oftentimes end up with "few alternatives for reproductive and preventive health care." 92 In 2014, a single mother from Washingtonville, Pennsylvania, who lived 74 miles away from the nearest RHCC in Harrisburg, was sentenced to serve a twelve-to-eighteen-months' sentence and pay a fine of $\$ 1,000$ after she induced an abortion upon her 16-year-old daughter, who refused to have the child.93 In Texas, 100,000 women have been found to be self-inducing abortions given the lack of RHCFs. ${ }^{94}$ Self-induced abortions are often done in dangerous conditions and involve additional health risks. 95

Second, many women feel these clinics are the only places where they can request reproductive services in an environment free of judgment, whether it is a simple gynecological checkup, birth control, a preventive screening, or an abortion. 96 According to Planned Parenthood's 2014-15 annual report, the Planned Parenthood

88 About Our Fees, Planned Parenthood, https://www.plannedparenthood.org/planned-parenthood-central-western-new-york/patient-resources/paying-your-health-care/about-our-fees. See also National Abortion Federation, https://www.prochoice.org/pubs_research/publications/downloads/about_abortion/abortion_title_x.pdf ("The majority of Title X clients are low-income, uninsured, and do not qualify for Medicaid.").

89 The Guttmacher Institute is a "leading research and policy organization" dedicated to researching and advancing reproductive health and rights in the United States and globally "through [an] interrelated program of research, public education, and policy analysis." Available at: <http://www.guttmacher.org/about>. Last accessed on Oct. 23, 2016.

90 NAPILI, Angela. Congressional Research Service, "Title X (Public Health Service Act) Family Planning Program," Sep. 26, 2016, at p. 18.

91 For example, the Texas Policy Evaluation Project signals the following as four reasons why women self-induce abortions: (1) Not having enough money to travel to a clinic or pay for the procedure; (2) The local clinic was forced to close; (3) A close friend or family member recommended self-inducement; and (4) The woman wanted to avoid the shame of being associated with going to an RHCC. See KHAZAN, supra note 26; BEUSMAN, supra note 25; WELCH, Ashley. "Study: 100,000 Texas women have tried to self-induce abortion", CBS News, Nov. 19, 2015. Available at: <http://www.cbsnews.com/news/100000-texas-women-have-tried-to-self-induce-abortion/.>.

92 WINTER, Meaghan. “The Stealth Attack on Abortion Access”, N.Y. Times: The Opinion Pages, Nov. 12, 2015. Available at: <http://www.nytimes.com/2015/11/12/opinion/the-stealth-attack-on-abortion-access. html?_r=3>.

93 DEKOK, David. "Pennsylvania mother who gave daughter abortion pill gets prison”, Reuters, Sep. 6, 2014. Available at: <http://www.reuters.com/article/us-usa-crime-pennsylvania-abortion-idUSKBN0H10IR20140906>.

94 KHAZAN, supra note 26; BEUSMAN, supra note 25; WELCH, supra note 91.

95 See KHAZAN, supra note 26; BEUSMAN, supra note 25; WELCH, supra note 91.

96 MILLER, Elizabeth. "An Open Letter to a Protester Outside the Boston Planned Parenthood this Saturday", Huffington Post: Huffpost Women Blog, Sep. 7, 2014:"I started going to Planned Parenthood in 1997, and since then have gotten all my reproductive health care there, because once inside, I feel respected and listened to, and able to access the medical care I need without judgement. Outside, however, it's another story." Available at: <http://www.huffingtonpost.com/elizabeth-miller/an-open-letter-to-a-protester-outside-the-boston-planned-parenthood_b_5553701.html>. 
Federation of America (PPFA) provided support to 59 independently incorporated affiliates, which operate the 661 health centers that served 2.5 million patients that year. ${ }^{97}$ These affiliated clinics performed 271,539 pap smears, 363,803 breast examinations, provided 2,945,059 birth control-related services, conducted 651,695 HIV tests, and diagnosed 171,882 sexually transmitted infections (STIs). 98 The medical services data section in that report reveals that, out of the total services provided by Planned Parenthood affiliates, $45 \%$ consisted of STI/STD testing and treatment, $31 \%$ was provision of contraception, $9913 \%$ was allocated to other women's health services, $1007 \%$ went to cancer screening and prevention, $3 \%$ were abortions, and the remaining $1 \%$ consisted of other services. ${ }^{101}$ In total, Planned Parenthood affiliates provided 9,455,582 services for the 2014-15 year. ${ }^{102}$

Despite the variety of services offered at RHCFs besides abortion, RHCFs continue to be referred to as "abortion clinics," a phrase U.S. Supreme Court Justice Ruth Bader Ginsburg has openly objected to because it attaches prejudice to a facility that, at the end of the day, provides medically necessary services. ${ }^{103}$

\subsection{Who is Seeking an Abortion?}

The incongruence between abortion opponents' intended and actual audience is a constant source of frustration for women who seek reproductive healthcare at an RHCF. A Boston woman narrated her personal experience with abortion opponents: "You could be going there, like in my case, for my yearly exam and I'm getting called 'baby-killer.' . . . you can't believe someone just yelled at you on the way to the doctor."104 Sarah Cyr-Mutty, a community relations coordinator for a Boston clinic, says that the crowd of people outside the facility makes the atmosphere tenser, more chaotic, and more uncomfortable for the patients. "No one wants to drive up to their doctor's

\footnotetext{
97 Planned Parenthood 2014-15 Annual Report at p. 5 [hereinafter 2014-15 Annual Report]. Available at: < https://www.plannedparenthood.org/files/2114/5089/0863/2014-2015_PPFA_Annual_Report_.pdf >.

98 Idem. at p. 28.

99 See idem. at p. 29 for further contraception data breakdown.

100 Michelle Ye He Lee defines "other women's health services" as pregnancy tests and "prenatal services." LEE, Michelle Ye Hee. "Fact Checker For Planned Parenthood abortion stats: '3 percent' and '94 percent' are both misleading", The Washington Post, Aug. 12, 2015. Available at: <https://www.washingtonpost.com/news/ fact-checker/wp/2015/08/12/for-planned-parenthood-abortion-stats-3-percent-and-94-percent-are-both-misleading/.>.

101 2014-15 Annual Report, supra note 97 at p. 29.

102 Idem. at p. 30.

103 "The Court's hostility to the right Roe and Casey secured is not concealed. Throughout, the opinion refers to obstetrician-gynecologists and surgeons who perform abortions not by the titles of their medical specialties, but by the pejorative label 'abortion doctor."' Gonzales v. Carhart, 550 U.S. 124, 186-87 (2007).

104 See FILIPOVIC, supra note 11 (Pia's testimony in video).
} 
office and see over 100 people standing outside."105 Another patient who was approaching the clinic entrance refused to speak to a woman handing out an anti-abortion pamphlet: "Honestly, I'm having a miscarriage right now, so I really don't feel like talking to you." $106 \mathrm{~A}$ demonstrator who observed the exchange dismissed the patient's remarks by claiming, "That's usually what they say... The new abortion mentality is no more of the 'choice' word. The thing is to claim that abortion is just a miscarriage."107

Women who seek reproductive healthcare from RHCCs do so for a myriad of reasons. The reasons for seeking an abortion specifically are just as diverse. 108 In light of the recent Whole Woman's Health v. Hellerstedt case, 109 the Center for Reproductive Rights 110 launched a campaign called "Draw the Line,"111 which gathered women's diverse abortion stories and showcased them on the project's website. The collection of stories reveals that, while some women seek an abortion to end an unplanned pregnancy, others do so due to medical conditions or reasons beyond their control, such as epilepsy or an ectopic pregnancy. 112

It is impossible for an anti-abortion demonstrator to ascertain that a patient entering an RHCF is doing so to receive an abortion. In order to ascertain that a woman is in fact seeking an abortion, an anti-abortion demonstrator would be forced to ask the patient directly. While the patient may have the option to decline to respond, oftentimes ignoring the demonstrators means enduring uncalled-for insults or yelling. Of course, it is just as impossible for patients to ascertain which demonstrators will desist immediately upon being ignored and which ones will continue prying. A woman who does not want to risk being yelled at, therefore, may feel like she has no choice but to explain herself. Is our position as a society that a political group's First Amendment rights are more important than a population's right to privacy and to obtain the reproductive healthcare they need and are entitled to?

\footnotetext{
105 PEARL, Diana. "Free Speech Outside the Abortion Clinic", The Atlantic, Mar. 19, 2015. Available at: <http:// www.theatlantic.com/health/archive/2015/03/free-speech-outside-the-abortion-clinic/388162/>.

106 FILIPOVIC, supra note 11.

107 Idem.

108 See CENTER FOR REPRODUCTIVE RIGHTS. "Actresses Share Real Abortion Stories: The Draw the Line Monologues." Available at: <https://www.youtube.com/watch?v=fwFpFirvF7E >.

109 Whole Woman's Health v. Hellerstedt, 790 F.3d 563 (2015), granting certiorari. In Whole Woman's Health v. Hellerstedt, 136 S. Ct. 2292 (2016), the U.S. Supreme Court ultimately struck down the challenged Texas statute, holding that the same imposed an undue burden on women's constitutionally protected right to access abortion.

110 The Center for Reproductive Rights is "the only global legal advocacy organization dedicated to reproductive rights." CENTER FOR REPRODUCTIVE RIGHTS. "About Us". Available at: <http://www.reproductiverights. org/about-us>. Last accessed Oct. 23, 2016.

111 Draw the Line, <http://www.drawtheline.org/>. Last accessed Apr. 19, 2016.

112 See CENTER FOR REPRODUCTIVE RIGHTS Video, supra note 108.
} 


\subsection{Who is a "Sidewalk Counselor"?}

The McCullen Court stated that "sidewalk counseling" involved "offering information about alternatives to abortion and help pursuing those options."113 However, it failed to explain what the requirements are to be accurately denominated a "sidewalk counselor." Throughout the many phases of the litigation, Petitioners in the McCullen case described themselves as "sidewalk counselors."114 The Court adopted this characterization and noted that these individuals "approach and talk to women outside such facilities, attempting to dissuade them from having abortions."115 Petitioners' argument worked. The State of Massachusetts conveyed the violent history of harassment against RHCFs, but did not press the Court on the "sidewalk counselor" point.116 Despite this being a crucial distinction in the case, the Court failed to define who counts as a sidewaIk counselor and who crosses the line to be fairly characterized as a more dangerous protester. In criticizing the Court's ruling in the McCullen case, Lithwick and West highlight the Court's ambiguity in this regard, stating:

In the abortion clinic context, counselors are the people who have the goal of providing a message to women entering the clinics that abortion is bad. These people, the court asserts 'are not protesters.' We'll know them when we see them, because they might pass out literature instead of carrying signs. They might also say, 'Good morning,' before telling you that abortion is bad. They have a 'caring demeanor,' a 'calm tone of voice,' and 'maintain direct eye contact.' They tend to be gray-haired grandmothers. 'Counselors' also have been spotted taking a moment to 'pray the rosary.' (Protesters, the court, cautions, do things like carry signs, chant together, or sometimes engage in 'more aggressive' tactics like face-to-face confrontation. $)^{117}$

Lithwick and West have a point: These so-called counselors are self-proclaimed. ${ }^{118}$ Anti-abortion activists, or self-proclaimed sidewalk counselors, often approach the women entering and exiting RHCCs under the assumption that they are seeking an abortion at the facility in the hopes that they can engage the women and offer

\footnotetext{
113134 S. Ct. at p. 2527.

114 See supra note 61 at *Add. 100a-101a ("Plaintiff Eleanor McCullen engages in sidewalk counseling ... She frequently works with another sidewalk counselor ...").

115 Idem. at p. 2525.

116 See, generally, Oral Argument, supra note 72.

117 See LITHWICK and WEST, supra note 78.

118 See e.g., 134 S. Ct. at p. 2549, where the Court accepted Petitioners' self-description as "sidewalk counselors" without further inquiry into such designation: "A sidewalk counselor, such as petitioners, enters the buffer zone, approaches the woman and says, 'If you have doubts about an abortion, let me try to answer any questions you may have. The clinic will not give you good information."' See also FILIPOVIC, supra note 11 ("Ruth and Evelyn call themselves 'sidewalk counselors,' not protesters.") (emphasis supplied).
} 
information about alternatives to abortion. 119 For instance, Petitioner Eleanor McCullen - the lead plaintiff in the McCullen case - typically initiates a conversation like this: "Good morning, may I give you my literature? Is there anything I can do for you? I'm available if you have any questions."120 There are three evident problems with this approach. First, how can Ms. McCullen realistically ascertain that she is approaching someone who is indeed seeking to have an abortion? Second, assuming the woman is in fact seeking an abortion, Ms. McCullen's disposition to answer any questions further assumes that the woman she has approached is not - or chooses not to be - conscious of what she is doing and aware of her options. The Hill Court explicitly acknowledged that people trying to access the clinics are in "particularly vulnerable physical and emotional conditions" that warrant the State's protection from "unwanted encounters, confrontations, and even assaults."121 More often than not, people in particularly vulnerable physical and emotional conditions - such as women who might be seeking an abortion - will have weighed their options mindfully before arriving at a conclusion as to what is the best course of action given their specific circumstances. Third, if the woman is in fact seeking an abortion, how can Ms. McCullen realistically help? Will she cover the medical expenses for any medical complications the woman may experience as a result of the pregnancy? Will Ms. McCullen provide financial support to the woman who carries the pregnancy to term and her child? Absent concrete criteria for someone to be designated a "sidewalk counselor," is it the Court's position that a "Hello, can I give you my literature?" or the outward characteristics and demeanor of a person are enough for them to claim "sidewalk counselor" status? One must wonder why Ms. McCullen, who has been described as "a sweet, cheerful grandmother from Massachusetts,"122 was specifically chosen as the lead plaintiff for the litigation.

From the perspective of women who seek reproductive healthcare at an RHCF, anti-abortion activism can range from being a simple nuisance to borderline, if not actual, harassment. In connection to this, Professor Chemerinsky noted that, "...the Court gave insufficient weight to the rights of those who are using or working at clinics and want to be free from verbal and physical assaults." 123 He further characterized the Court's opinion as an "open invitation to arbitrary line drawing."124

\footnotetext{
119134 S. Ct. at p. 2527.

120 Idem.

121 Hill, 530 U.S. at p. 729.

122 BOWMAN, Matt. "A Quiet Grandmother Wins One for Free Speech at the Supreme Court", Wash. Times, Jul. 1, 2014. Available at: <http://www.washingtontimes.com/news/2014/jul/1/quiet-grandmother-wins-one-free-speech-supreme-cou/.>.

123 CHEMERINSKY, Erwin. Appearances can be Deceiving. Green Bag Online, Washington, vol. 17, n. 4, p. 389404, jun./aug. 2014, at p. 397.

124 Idem.
} 


\subsection{Buffer Zones in Other Contexts}

The use of buffer zones has not been limited to reproductive health clinics. ${ }^{125}$ Polling places, military funerals, government buildings, and federal courthouses, including the U.S. Supreme Court, are some of the facilities or contexts that reap the benefits of having a protective buffer zone around their premises. The Supreme Court's buffer zone law, for example, makes it "unlawful for protesters to demonstrate on Supreme Court building grounds." 126

\subsubsection{The (Military) Funeral Context}

In Snyder v. Phelps, 127 Marine Lance Corporal Matthew Snyder had been killed in the line of duty in Iraq. 128 The details for the fallen soldier's funeral services, which would be held in Maryland, were announced in the local newspapers. 129 Members of the Westboro Baptist Church of Topeka, Kansas, who were of the view that God punishes the United States for its tolerance of homosexuality in the military by killing American soldiers, decided to travel to Maryland and picket Snyder's funeral procession. ${ }^{130}$ Standing in a land adjacent to a public street, the Westboro picketers sang hymns and displayed signs that stated, "God Hates the USA/Thank God for 9/11,"'America is Doomed," "Don't Pray for the USA," "Thank God for IEDs," "Thank God for Dead Soldiers," "Pope in Hell,"'Priests Rape Boys," "God Hates Fags,",'You're Going to Hell," and "God Hates You."131 Snyder's father was not able to see what was written on the signs until he saw a news broadcast of the event later that evening. ${ }^{132}$ He then filed a suit in the U.S. District Court for the District of Maryland based on tort law against the Westboro picketers and the Church itself, alleging defamation, publicity given to private life, intentional infliction of emotional distress (IIED), intrusion upon seclusion, and civil conspiracy.133 After the jury awarded Snyder $\$ 2.9$ million 134 in damages at the district court level, the Court of Appeals sided with the Defendants' contention that the First Amendment "fully protected

\footnotetext{
125 See ANNEAR, Steve. “The Supreme Court Technically Has Its Own 252-Foot Buffer Zone”, Boston Daily, Jun 26, 2014. Available at: <http://www.bostonmagazine.com/news/blog/2014/06/26/supreme-court-buffer-zone-regulations/>.

126 ANNEAR, supra note 125.

127 Snyder v. Phelps, 562 U.S. 443 (2011).

128 Idem. at p. 448.

129 Idem.

130 See idem.

131 Idem.

132 Idem. at p. 449.

133 Idem. at pp. 449-50.

134 The District Court later remitted the punitive damages award to $\$ 2.1$ million. 562 U.S. at p. 450.
} 
Westboro's speech"135 and reversed the judgment.136 On certiorari, the question before the U.S. Supreme Court was whether the First Amendment protects church members picketing near a soldier's funeral service from tort liability. ${ }^{137}$ The question would turn on whether the Westboro Church members' speech was a matter of public or private concern. ${ }^{138}$

The Supreme Court noted that the First Amendment grants special protection to speech related to public concerns, 139 but that the same rigorous protection does not extend to speech related to private matters. ${ }^{140}$ In order to decide whether Westboro's speech was related to private or public matters, the Court employed the Connick test, ${ }^{141}$ which requires the examination of the content, form, and context of the speech as revealed by the whole record. ${ }^{142}$ The Court ruled that the content of Westboro's message pertained to broader public issues and that the context of the funeral procession did not alter that conclusion. ${ }^{143}$ Recognizing that Westboro's speech was also subject to time, place, and manner restrictions, the Court concluded that Westboro was exempt from tort liability because the picketing was conducted about 1,000 feet away from the church, without disrupting the funeral. ${ }^{144}$

"Speech is powerful. It can stir people to action, move them to tears of both joy and sorrow, and - as it did here - inflict great pain. On the facts before us, we cannot react to that pain by punishing the speaker. As a Nation we have chosen a different course - to protect even hurtful speech on public issues to ensure that we do not stifle public debate."145

Both parties in this case benefitted from the buffer zone in place. Even when the funeral procession passed within 200 or 300 feet of the picket site, the distance prevented Mr. Snyder from seeing what was written on the picket signs or hearing the protesting until he watched the news later that evening. ${ }^{146}$ Had the picketers disrup-

\footnotetext{
135 Idem.

136 Snyder v. Phelps, 580 F.3d 206, 211 (4th Cir. 2009).

137 See 562 U.S. at p. 447.

138 Idem at pp. $444,451$.

139 See idem. at pp. 451-52 (drawing the distinction between matters of public and private concern).

140 See idem. at p. 452.

141 Connick v. Myers, 461 U.S. 138, 147-48 (1983); Dun \& Bradstreet, Inc. v. Greenmoss Builders, Inc., 472 U.S. 749, 758-59, 761 (1985).

142562 U.S. at p. 444: "To determine whether speech is of public or private concern, th[e] Court must independently examine the 'content, form, and context,' of the speech 'as revealed by the whole record."'

143562 U.S. at pp. 454-56.

144 Idem. at p. 457.

145 Idem. at pp. 460-61.

146 Idem. at pp. $449,462$.
} 
ted the funeral procession, made it so that Mr. Snyder was able to see what the signs were displaying or hear the picketers' message, his IIED claim would have been stronger and Westboro would have probably been found liable. It was the church members' obedience to the authorities' instructions as to how to stage their demonstration that shielded them from liability. ${ }^{147}$

At least seventeen states 148 have enacted state statutes that explicitly prohibit protesting or picketing funeral processions in order to protect families' grieving process. ${ }^{149}$ Out of those seventeen states, at least Arkansas, Arizona, California, Colorado, Florida, Georgia, Massachusetts, Mississippi, Missouri, Montana, Nebraska, New Hampshire, Oklahoma, Pennsylvania, and Wyoming - fifteen states - enforce protective buffer zones around the funeral procession or site, ranging from 100 feet to 1,500 feet. 150 In addition, some states regulate when the demonstration might take place. For instance, Arkansas prohibits picketing the funeral during and within the thirty minutes immediately preceding or following the ceremony.151 Georgia, on the other hand, prohibits demonstrations targeted at a memorial service from occurring "at any time one hour prior to, during, or one hour after the posted time."152 The classification of the offense also varies by state. For example, Arkansas, Arizona, Florida, South Dakota, and Wyoming are some of the states that classify the offense as some kind of misdemeanor, while California imposes criminal penalties. 153 If our laws recognize that mourning relatives' vulnerable emotional state merit protection, why is a woman's emotional state and desire for privacy treated differently by the courts?

\footnotetext{
147 Idem. at pp. 448-49.

148 Arizona (Ariz. Rev. Stat. Ann. § 13-2930 (2011)), Arkansas (Ark. Code Ann. § 5-71-230 (West 2013)), California (Cal. Penal § 594.37 (West 2013)), Colorado (Colo. Rev. St. Ann. § 13-21-126 (West 2006)), Florida (Fla. Stat. $\S 871.015$ (2014)), Georgia (Ga. Code Ann. § 16-11-34.2 (West 2006)), Kentucky (Ky. Rev. Stat. Ann. §525.155 (West 2007)), Massachusetts (Mass. Gen. Laws Ann. ch. 272 § 42A, Mississippi (Miss. Code Ann. § 97-35-18 (West 2006)), Missouri (Mo. Ann. Stat. § 574.160 (West 2014)), Montana (Mont. Code Ann. § 45-8-116 (West 2007)), Nebraska (Neb. Rev. St. Ann. § 28-1320.02 (West 2011)), New Hampshire (N.H. Rev. Stat. Ann. § 644:2-b (2007)), Oklahoma (Okla. Stat. Ann. tit. $21 \S 1380$ (West 2011)), Pennsylvania (tit. 18 Pa. Stat. and Cons. Stat. Ann. § 7517 (West 2006)), South Dakota (S.D. Codified Laws § 22-13-17 (2006)), and Wyoming (Wyo. Stat. Ann. § 6-6-105 (West 2011)).

149 For example, Colo. Rev. St. Ann. § 13-21-126(1)(b) explicitly recognizes that "[f]uneral picketing disrupts the grieving process" and that it "intentionally inflicts severe emotional distress on the mourners." Subsection (A)(1) (b) of Okla. Stat. Ann. tit. $21 \S 1380$ and Subsection (a)(2) of tit. 18 Pa. Stat. and Cons. Stat. Ann. § 7517 provide that "the interests of families in privately and peacefully mourning the loss of deceased relatives are violated" when funerals or commemorative services are "targeted for picketing and other public demonstrations..."

150 See supra note 148.

151 Ark. Code Ann. § 5-71-230(b)(3).

152 Ga. Code Ann. § 16-11-34.2(b)(4).

153 Cal. Penal $\S 594.37$ (b) provides: "Any violation of subdivision (a) is punishable by a fine not exceeding one thousand dollars $(\$ 1,000)$, imprisonment in a county jail not exceeding six months, or by both that fine and imprisonment."
} 


\subsubsection{The Polling Place Context}

Buffer zone laws are also enforced around polling places. ${ }^{154}$ For example, in 1992, the Supreme Court considered the constitutionality of a Tennessee election statute, which prohibited "the display of campaign posters, signs or other campaign materials, distribution of campaign materials, and solicitation of votes for or against any person, political party, or position on a question" within 100 feet of entrances to polling places. ${ }^{155}$ The statute allowed the authorities to extend the election-day "campaign-free zone" 156 by private action based on the size of the population.157 The buffer zone statute was challenged on First Amendment grounds 158 because (1) it regulated political speech, (2) the regulation of the political speech was occurring in a public forum, and (3) the regulation was based on the content of the speech.159 The State of Tennessee articulated two interests served by the buffer zone statute. First, the statute protects the rights of its citizens to vote freely for the candidates of their choice. ${ }^{160}$ Second, that the restriction protects the right to vote in an election conducted with integrity and reliability. ${ }^{161}$ Notwithstanding the Court's finding that the statute was content-based, the Court also recognized the State's interests in "protecting voters from confusion and undue influence" were legitimate and compelling162 and that the law as written was necessary to serve those interests. ${ }^{163}$ The plurality acknowledged that it is rare for a law to survive the Court's strict scrutiny analysis and upheld the constitutionality of the law. ${ }^{164}$ Finally, and most significantly for our purposes, the Court admitted that "[v] oter intimidation and election fraud are successful precisely because they are difficult to detect. 165 If an individual purporting to intimidate voters is hard to discern, how can the authorities, clinic staff, and women be expected to discern a violent anti-abortion protester from a peaceful one in the RHCF context? In fact, an officer who was present on the day John C. Salvi III opened fire on two Brookline clinics and killed two women

\footnotetext{
154 HO, Daniel E.; SCHAUER Frederick. Testing the Marketplace of Ideas. New York University Law Review, New York, vol. 90, n. 4, pp. 1160-1228, oct. 2015. p. 1178.

155 Idem.

156 Burson v. Freeman, 504 U.S. 191, 193 (1992).

157 Tenn. Code Ann. § 2-7-111(d) (West 2003).

158504 U.S. at p. 195.

159 Idem. at p. 196.

160 Idem. at p. 198.

161 Idem. at p. 199.

162 Idem.

163 Idem. at pp. 210-11.

164 Idem. at p. 211.

165 Idem. at p. 208.
} 
stated there was nothing about Salvi's demeanor that suggested that he was about to violently attack one of the clinics. 166

\subsubsection{The Buffer Zone Around the Supreme Court}

In 1949, a federal statute established a buffer zone around the U.S. Supreme Court grounds. ${ }^{167}$ Currently, the statute, which is codified at Section 6135 of Title 40, consists of two clauses within one sentence. ${ }^{168}$ The first clause, referred to as the Assemblages Clause by the Supreme Court, makes it unlawful "to parade, stand, or move in processions or assemblages in the Supreme Court Building or grounds."169 The second clause, known as the Display Clause, makes it unlawful to "display in the Building and grounds a flag, banner, or device designed or adopted to bring into public notice a party, organization, or movement."170 It is worth noting that the statute was written in such a way as to include the plaza in front of the Supreme Court building as part of its "grounds."171

The constitutionality of the statute was challenged by a college student who was arrested for displaying a sign on the Supreme Court's plaza in the Hodge v. Talkin case. The student, Harold Hodge, Jr., brought the action on First and Fifth Amendment grounds, alleging that the Assemblages and Display clauses were overbroad and unconstitutionally vague and, thus, unconstitutionally restrictive upon his right to free speech.172 After the District Court had entered summary judgment for the student, the U.S. Court of Appeals for the D.C. Circuit reversed, holding that the Supreme Court plaza constituted a "nonpublic forum" for purposes of the First Amendment and that the statute was a reasonable limitation on speech. ${ }^{173} \mathrm{~A}$ petition for certiorari review was filed on January 6, 2016 with the Supreme Court, but the Court denied certiorari on May 16, 2016. 174

The applicable First Amendment analysis was dependent on whether the plaza constituted a public forum or a nonpublic forum. In the Hodge opinion, Judge

\footnotetext{
166 CHILDRESS, Sarah. “Murder on Abortion Row”, Frontline (PBS), Jun. 26, 2014. Available at: <http://www. pbs.org/wgbh/pages/frontline/social-issues/watch-murder-on-abortion-row/>.

167 JACOBY, Jeff. "Strike down the Supreme Court's 'buffer zone'”, Boston Globe: Opinion, Sep. 6, 2015. Available at: <https://www.bostonglobe.com/opinion/2015/09/05/free-speech-buffer-zone-supreme-court-plaza-ludicrous/lh3lmBDFgVNAvu7bLHFuRP/story.html>.

16840 U.S.C. § 6135; Hodge v. Talkin, 799 F.3d 1145, 1149 (2015).

16940 U.S.C. $§ 6135 ; 799$ F.3d at p. 1149.

170 Supra note 169.

171799 F.3d at pp. 1149, 1150-51. See 40 U.S.C. $§ 6101(b)(1)$ (defining the limits of the Supreme Court grounds, which extend to the curbs of the sidewalks, but exclude the sidewalks themselves).

172799 F.3d at p. 1154.

173 Idem. at p. 1162.

174 See Hodge v. Talkin, 136 S. Ct. 2009, denying certiorari.
} 
Srinivasan cited a statement authored by Justice Breyer to explain why the plaza is considered a nonpublic forum for First Amendment purposes: "Starting at the Court's western plaza, Gilbert's plan leads visitors along a carefully choreographed, climbing path that ultimately ends at the courtroom itself."175 Because "the government retains substantially greater leeway to limit expressive conduct in such an area..." - namely, a nonpublic area - , "the government can impose reasonable restrictions on speech" as long as no one viewpoint is repressed. 176 The Court reasoned that the statute served the government's "interests in preserving decorum in the area of a courthouse and in assuring the appearance (and actuality) of a judiciary uninfluenced by public opinion and pressure," thus concluding that the law was a constitutional restriction. ${ }^{177}$ The opinion considered "the sidewalk area directly in front of the Court's plaza" evidence of the statute's reasonableness. 178

Speech can be powerful. As a nation, we have chosen to protect hurtful speech to not stifle public debate. We have, however, also chosen to grant grieving families at a funeral procession with the minimum protection and courtesy of a buffer zone so they may mourn in peace. We have also chosen to uphold campaign-free zones around polling places to protect voters from undue influence and intimidation. Our federal courts have chosen to uphold a buffer zone statute around the U.S. Supreme Court to preserve decorum and an uninfluenced judiciary. We have, somehow, found ways to make these buffer zones coexist with First Amendment rights. What makes reproductive healthcare clinics so different? Why can we not extend the same minimum protection to women? Erwin Chemerinsky, Dean of the UC Irvine School of Law and renowned constitutional law professor, has argued: "Those going into clinics should not have to be yelled at, shown graphic photographs, called names, and made to fear for their safety. Women exercising their constitutional rights should be protected from harassment."179 No woman who seeks the reproductive healthcare she is entitled to - whatever it may be - should feel forced or compelled to explain her circumstances and why she is seeking medical attention from an RHCF when approached by a stranger on a sidewalk — regardless of whether she is in fact emotionally vulnerable or not.

\footnotetext{
175 J. Stephen Breyer, Statement Concerning the Supreme Court's Front Entrance, 2009 S. Ct. J. 831, 831 (2010).

176799 F.3d at p. 1150.

177 Idem.

178 Idem.

179 CHEMERINSKY, supra note 123, at pp. 397-98.
} 


\section{CONCLUSION}

In the Hill decision, the Court recognized that healthcare facilities are surrounded by unique concerns and circumstances. The Court reasoned that hospital patients are oftentimes in a vulnerable emotional state, which begs for a comforting and supportive atmosphere. In the Snyder decision, the Court recognized that the Westboro church members were free from liability because they abided by the buffer zone laws in place in order to protect the grieving family's frail emotional state during the mourning process. The Supreme Court upheld a Tennessee statute around polling places in order to protect voters from intimidation and undue influence. The U.S. Supreme Court's own buffer zone has been upheld to preserve the Court's decorum and an uninfluenced judiciary. Why are courts hesitant to extend the same minimum protection to the women who seek access to RHCFs? Are these women not entitled to privacy? What makes the reproductive healthcare context so different from other contexts? My research revealed no evidence of a need for protective buffer zones around hospitals. If an abortion may also be performed in a mainstream hospital, why are they not also subject to similar aggressions? What makes RHCCs so different in nature?

If upholding a buffer zone statute may be considered an endorsement of the pro-choice viewpoint over the anti-abortion movement, then striking down said statute can be interpreted as a prioritization of the anti-abortion viewpoint. I suggest this binary is too broad. First, women seek reproductive care from physicians and staff at RHCFs on a daily basis for a wide variety of reasons. Many women recur to these clinics seeking routine pap smears, birth control, breast cancer and STD/STI screenings, and many other services that might be more costly or more time-consuming if received at a hospital. Moreover, sometimes an RHCF is the only available health facility for miles. Second, the women who in fact seek an abortion more often than not do so after having weighed their options heavily, wondered about the looming possibility of regret, concluding that this is the best choice for them and their families. Failing to uphold buffer zone statutes that protect these women's privacy leaves them with two choices: To either ignore anti-abortion demonstrators at the risk of being yelled at or divulge the reasons why they are seeking medical care at these facilities. Judge Karen Schreier, a South Dakota federal judge, wrote in an opinion: "Forcing a woman to divulge to a stranger at a pregnancy help center the fact that she has chosen to undergo an abortion humiliates and degrades her as a human being."180 The buffer zone debate has long been articulated as a First Amendment issue, but I suggest it is more practically a women's privacy and dignity issue.

180 Planned Parenthood Minn., N.D., S.D. v. Daugaard, 799 F. Supp. 2d 1048, 1060 (2011); “The Courts Step In", N.Y. Times: Opinion, Jul. 13, 2011. Available at: <http://www.nytimes.com/2011/07/14/opinion/14thurs1. $h t m l ?$ r $=0 .>$. 
The McCullen Court unanimously asserted that, "petitioners are not protesters," but failed to provide further guidance as to where to draw the line. Indeed, who counts as a sidewalk counselor? Is it anybody who self-proclaims to be one? Is it an elderly woman handing out a leaflet? Does a 35-year-old man standing silently outside a clinic with a sign displaying an aborted fetus count as one or does he cross the line? Is he deemed a more aggressive protester? Why?

Drawing the line between who is an aggressive abortion opponent and who is not is difficult not just for the Supreme Court, but also for the women who seek reproductive healthcare and for the authorities of the State that are trying to maintain the peace. Similarly, assuming abortion opponents approach these women with the best of intentions, it is nearly impossible for them to ascertain who among the many women approaching an RHCC is seeking an abortion without invading their privacy. As a result, they target every woman who seems to be approaching the nearest clinic, regardless of the reason. What are these women supposed to do? Are they supposed to tell a stranger they are not seeking an abortion to appease them? Are they supposed to ignore them in the hopes that they will desist? If they opt for ignoring them, are these women supposed to endure being yelled at? Are they supposed to tolerate being called "baby-killer" or "gross" for the sake of abortion opponents' First Amendment rights? What about women who are seeking an abortion? Do they not have the right to their privacy? Do they not have the right to have a few moments to themselves before making what might be the hardest choice they have ever made? If we consider protecting mourning, emotionally vulnerable families during funeral proceedings from further emotional distress a legitimate state interest, why is a woman's emotional vulnerability not regarded in the same way? If we are willing to enforce buffer zones around polling places to protect voters from voter intimidation and undue influences, so as to preserve the integrity of our democratic system, why are we reluctant to extend the same consideration to women who feel intimidated for seeking the reproductive care they are entitled to and need?

Contrary to the Supreme Court's buffer zone, buffer zones around RHCCs are not meant to preserve decorum or to assure the appearance and actuality of an uninfluenced judiciary. Buffer zones around RHCFs are necessary to protect patients from unsolicited advice, "counsel," and even harassment. They are needed to safeguard women's right to privacy. Regardless of which side of the debate one subscribes to, no American will contend that a fellow citizen has a lesser right to privacy. Restricting the time, place, and manner in which anti-abortion demonstrations happen would only marginally reduce the area where the free speech may take place in exchange for patients' increased sense of respect, privacy, and overall human dignity. 


\section{REFERENCES}

ALBERT, Richard. Protest, Proportionality, and the Politics of Privacy: Mediating the Tension Between the Right of Access to Abortion Clinics and Free Religious Expression in Canada and the United States. Loyola of Los Angeles International and Comparative Law Review, Los Angeles, vol. 27, n. 1, p. 1-62, jan./apr. 2005.

CHEMERINSKY, Erwin. Appearances can be Deceiving. Green Bag Online, Washington, vol. 17, n. 4, p. 389-404, jun./aug. 2014.

COWAN, Kristen G. The Tailoring of Statutory Bubble Zones: Balancing Free Speech and Patients' Rights. Journal of Criminal Law \& Criminology, Boston, vol. 91, n. 2, p. 385-428, dic./mar. 2000/2001.

EDWARDS, Jamie. McGuire v. Reilly: The First Amendment and Abortion Clinic Buffer Zones in the Wake of Hill v. Colorado. UC Davis Law Review, Davis, vol. 36, n. 3, p. 787-812, feb. 2003.

FINER, Lawrence B.; FROHWIRTH Lori F. et al.. Reasons U.S. Women Have Abortions: Quantitative and Qualitative Perspectives. Perspectives on Sexual and Reproductive Health, [s.I.], vol. 37, n. 3, p.110-118, sep. 2005.

HO, Daniel E.; SCHAUER Frederick. Testing the Marketplace of Ideas. New York University Law Review, New York, vol. 90, n. 4, p. 1160-1228, oct. 2015.

HODGSON, Jane E. Violence Versus Reproductive Health Care: In The United States Organised Medicine Averts Its Gaze. British Medical Journal, London, vol. 310, n. 6979, mar. 1995.

SUTER, Sonia M. The "Repugnance" Lens of Gonzales v. Carhart and Other Theories of Reproductive Rights: Evaluating Advanced Reproductive Technologies. The George Washington Law Review, Washington, vol. 76, n. 6, p. 1514-1598, nov./dic. 2008. 